DOI: 10.20472/IAC.2018.039.006

\author{
KUAN-YANG CHEN \\ National Taipei University of Nursing and Health Sciences, Taiwan
}

CHIH-HUI HSIAO

National Chiayi University, Taiwan

PO-YUAN CHEN

National Dong Hwa University, Taiwan

CHENG-FEI LEE

Shih Chien University, Kaohsiung Campus, Taiwan

\title{
THE RELATIONSHIPS AMONG DIFFERENT TYPES OF MARKET KNOWLEDGE, AMBIDEXTROUS LEARNING, AND DIFFERENT TYPES OF INNOVATIONS
}

\begin{abstract}
:
In the knowledge economy era, both academia and industry alike have been focused on the impact of market knowledge on innovation performance. However, research addressing the inconsistencies in empirical findings about its impact (such as a negative or insignificant affect) is scarce. Moreover, ambidexterity (exploratory learning/exploitative learning) is one of the central topics in knowledge management. This article marks the first endeavor to adopt the knowledge-based theory and the ambidextrous learning perspective, attempt to create a theoretical framework of knowledge-learning-innovation, and thoroughly examine related causal relationships between different dimensions of the constructs. The empirical results demonstrated the following: market knowledge depth directly and positively impacts process innovation and product innovation; market knowledge breadth indirectly and positively impacts process innovation and product innovation; and there is no significant difference in the effects of the two types of knowledge on the two types of innovation performance. Ambidextrous learning directly and positively affects process innovation and product innovation; ambidextrous organizational learning mediates the effect of market knowledge breadth on process innovation and product innovation, and this mediating effect is more pronounced with exploitative learning; ambidextrous organizational learning does not mediate the effect of market knowledge depth on both types of innovation performance.
\end{abstract}

\section{Keywords:}

market knowledge (depth and breadth), ambidextrous learning, process innovation, product innovation

JEL Classification: M10 


\section{Introduction}

Due to radical market changes, firms need continuously updated market information so they can innovate and create sustainable competitive advantages (Chang, Bai, and Li, 2015). Research has found that it is not market orientation but rather unique market knowledge and the capability to operationalize such knowledge to innovate that enables firms to maintain their long-term competitive advantages (Kumar, Jones, Venkatesan, and Leone, 2011). This is because, despite their market-oriented business operations, firms possess different levels of market knowledge and those with higher levels of market knowledge are more likely to bring forth innovations (De Luca and Atuahene-Gima, 2007). Hence, it is more important to examine the relationship between market knowledge and innovation performance rather than the relationship between market orientation and innovation performance (Ferreras-Méndez, Newell, Fernández-Mesa, and Alegre, 2015; Verganti, 2009).

Although there should be a definite correlation between market knowledge and innovation performance, many studies of late have found that the effect of market knowledge on innovation performance varies (Bao, Sheng, S., and Zhou, 2012). For example, some studies found that market knowledge was important for firm innovation (Bruni and Verona, 2009; Wu and Shanley, 2009) or that market knowledge positively affected product development (Kim and Atuahene-Gima 2010; Li and Calantone 1998; Moorman 1995). However, other studies showed that market knowledge negatively impacted product innovation (Im and Workman, 2004). Bao et al. (2012) believe that such inconsistent results could be attributed to the fact that these studies failed to thoroughly examine what is brought about by the specific aspects of market knowledge, such as knowledge breadth and depth. Therefore, viewing market knowledge as a single overall construct when examining its relationship with innovation would actually taint this research (Chen and Lee, 2017; Ferreras-Méndez et al., 2015). Furthermore, from the perspective of actual practice, some manufacturers (e.g., branded manufacturers) value product innovation, whereas others (e.g., OEMs) value process innovation in the value chain. There are clearly different types of innovation performances as well. In other words, the inconsistent findings on the effects of market knowledge on innovation performance could also be attributed to failing to examine the different types of innovation performance. Empirical study results could even demonstrate an insignificant relationship between (particular types of) market knowledge and (particular types of) innovation performance.

In addition, insignificant findings on the effect of market knowledge on innovation performance could also be attributed to the lack of investigation into the effect of potential mediating mechanisms. Unlike physical resources, which are appropriable, meaning either you have it or I have it, in the case of information, we can both have it (Glazer, 1991). Hence, in light of the knowledge-based theory (KBT) of the firm, Tsou and Chen 
(2012) proposes the notion of knowledge integration mechanism (KIM) and its mediating effect, market knowledge, with its various dimensions, needs to exert its effect through the mediating mechanism of $\mathrm{KIM}$. In other words, the causal relationships between market knowledge and innovation performance need to be examined in the framework of input (knowledge resources) - process (system mechanism) - output (innovation performance), in order to explain why some firms deliver better innovation performance than others, despite the fact that they are all in possession of market knowledge.

From the perspective of organizational learning capability, the current study extends the input-process-output context, putting forward the possibility that corporate ambidextrous learning is a key to whether market knowledge can be effectively translated into innovation performance (Kostopoulos, Papalexandris, Papachroni, \& loannou, 2011). The ambidexterity theory advocates that firms can strike a balance between exploratory and exploitative learning and pursue both strategies simultaneously (March, 1991). According to the discipline of organizational behavior, ambidextrous learning, like dynamic capabilities, serves as an important knowledge integration mechanism that enables a firm to integrate, establish, and reorganize internal and external knowledge and skill sets in a dynamic environment in order to create innovation performance ( $O$ ' Reilly \& Tushman, 2008; Zhou and $\mathrm{Li}, 2012$ ). Although past research has examined the effect of ambidextrous learning on innovation, few studies have investigated the level of reliance in the relationships between different types of knowledge and innovation performance on different types of learning capabilities. In other words, few studies have examined the mediating roles played by different modes of organizational ambidextrous learning on the relationships between different market knowledge schemas and innovation performance (Chen, Li, \& Liu, 2015). This is the very contribution that the current study hopes to provide.

The first part of this study delves into the knowledge-based theory of the firm from the perspective of ambidextrous organizational learning, refining an only whole and single construct, namely market knowledge and innovation performance, into the two separate constructs of market knowledge breadth and depth and process and product innovation, exploring them each individually from the standpoint of how they affect different epistemologies in different causal models of innovation performance through the mediation of ambidextrous organizational learning.

To sum up, the purpose of current studies to investigate what effect do different market knowledge schemas have on different types of innovation performances, essentially which schemas of market knowledge have a relatively significant effect on which particular types of innovation; another purpose is to explore how to mediate the effects of different types of market knowledge on innovation performance with organizational learning capability. 


\section{Introduction}

\subsection{Market knowledge depth and innovation performance}

Drawing from the knowledge-based theory of the firm, De Luca and Atuahene-Gima (2007) proposed the following four attributes of market knowledge: depth, breadth, tacitness, and specificity. In particular, information depth and breadth have been examined the most frequently by scholars in fields as wide and varied as science and technology and customer service. The depth of market knowledge refers to the degree of knowledge that firms possess about certain market aspects-such as customers, competitors, suppliers, or other stakeholders on the market-or the sum of knowledge that firms possess about a particular market aspect (De Luca and Atuahene-Gima, 2007). This knowledge may pertain to customer relationship management as well as customer's psychology and behaviors. In addition, customer profiling-whether or not firms can accurately profile their target customers based on demographics (converting information into knowledge) - is a key that impacts their profitability (Chen and Lee, 2017).

As Christensen (2006) document, when a firm has developed deep knowledge and core competencies, in the form of technical or professional expertise, it tends to engage in activities in its existing, specialized domains. Some scholars noted in supply chain research that, with the accumulation of knowledge about the wafer OEM, semiconductor manufacturers could convert such knowledge into best practices to facilitate the development of new manufacturing processes (Clark, 2010). By activating the integration and use of best practices within the firm, knowledge sharing accentuates its selfreinforcing cycle of competence. As a result, the firm develops increasingly efficient processes and routines (Zhou and Li, 2012). This is because process innovation is extremely knowledge-intensive at the technological level and is enabled through changing tools and apparatuses in the process (Gopalakrishnan and Damanpour, 1997).

In general, firms with depth of market knowledge also possess stronger powers of perception and a more advanced knowledge hierarchy. In the past, scholars argued that the advantage of such firms could be manifested in product innovation (Bao et al., 2012; ). This is because firms have built a more thorough understanding about products or services on the market of a particular field-depth of market knowledge-and become knowledgeable about the history and the background of these products or services. Once such knowledge reaches a sufficient level, it is easier for the firm to envision how products or services may evolve in the future and in turn seize the opportunity to innovate (Dougherty, Borrelli, Munir, and O'Sullivan, 2000). The current study proposes the following hypothesis:

H1-a: Firms' market knowledge depth positively affects process innovation

H1-b: Firms' market knowledge depth positively affects product innovation 


\subsection{Market knowledge breadth and innovation performance}

The breadth of market knowledge describes the firm's knowledge about customers or competitors in their respective industries, or other types of knowledge. In other words, the types of knowledge possessed by a firm characterize its breadth of knowledge. Therefore, the concept of knowledge breadth is used as the basis of investigation in the current study. Schindehutte, Morris, and Kocak (2008) expands the definition of market knowledge to include not only customer knowledge but also suppliers' needs and the knowledge related to all the stakeholders. Knowledge about all these aspects allows firms to function and manage all operational activities.

Because business processes involve multiple departments, it will be easier for firms with broad market knowledge to engage in the creation of value. As market knowledge can come from customers, products, information technology, suppliers, competitors, other stakeholders, or the Internet (e.g., Schindehutte et al., 2008), it will be easier for firms with broader knowledge to establish operational processes that reduce production costs and increase production efficiency (Johnson, Christensen, \& Kagermann, 2008).

In general, broad market knowledge could mean possessing a lot of information that covers a wide spectrum, which could stimulate a firm's ability to quickly develop new ideas and formulate new product management views (De Luca and Atuahene-Gima, 2007; Bao et al., 2012). As firms become more knowledgeable about the entire market landscape (like the breadth of market knowledge), they will be more capable of providing products or services to meet the market demands (Morgan, Zou, Vorhies, Katsikeas, 2003). The current study proposes the following hypothesis:

H2-a: Firms' market knowledge breadth positively impacts product innovation

H2-b: Firms' market knowledge breadth positively impacts process innovation

\subsection{Ambidextrous Learning as a Mediating Mechanism}

Ambidextrous learning is drawn from the concepts of absorptive capability and organizational learning theory (Cohen and Levinthal, 1990; March, 1991). Scholars argue that firms need to consider how to internalize external resources (such as knowledge and technology) once such resources are introduced internally before firms can innovate. Later, scholars study the effect of knowledge resources on firms' performance by the perspective of learning capability (e.g., Nieves and Haller, 2014). However, this approach is flawed as it relies on one single construct to examine learning capabilities (e.g., Jansen et al., 2005). Therefore, subsequent research (after earlier studies adopting this absorption-based framework to examine firm's acquisition of knowledge from the market) uses organizational ambidextrous learning to explain how firm's knowledge affects innovation (e.g., Ferreras-Méndez et al., 2015). This means that firms must be equipped with outside-in oriented learning capabilities (exploratory learning) and inside-out oriented learning capabilities (exploitative learning) in order to adapt to environmental changes 
(Zhou and Li, 2012). From the perspective of organizational learning, firms with strong learning capabilities can identify new knowledge and skill sets, and, through internalization and sharing, implement innovative changes to products and processes. For example, Tzokas et al. (2015) examined how firm's learning capabilities mediated the causal relationship between firm's technological capabilities as well as customer relationships (i.e., customer knowledge) and the overall organizational performance (including financial and innovation performance). The present study thus posits the following hypothesis:

H3-a: Organizational ambidextrous learning (exploratory, exploitative) positively impacts innovation performance (process, product).

The logic in the framework of input-process-output explains how the market knowledge acquired by firms can yield innovation performance through the mediating mechanism of organizational learning and internalization. Hence, scholars recommend that future investigations of the uncertain relationships between market knowledge and firm's innovation performance should incorporate the mediating mechanism of exploratory and exploitative learning capabilities, in order to more clearly understand the causal relationships discussed in the above (Bao et al., 2012). Some studies point out that exploitative learning can help firms to innovate on existing products or improve the effectiveness of operational processes so as to facilitate product or process innovations (Kale and Singh, 2007). By the same token, the focus of exploitative learning is on firms extrapolating and extending existing knowledge or applying it to existing products or services on the market.

Therefore, firms with a great depth of market knowledge can, further increase the opportunity for product innovations and for commercial opportunity development through exploratory learning, to expand the firm's innovation foundation (Amara and Landry, 2005). Hence, the current study proposes the following hypothesis:

H3-b: Ambidextrous learning (exploratory and exploitative) mediates the positive relationship between market knowledge depth and innovation performance (process, product).

The proposition that market knowledge breadth impacts innovation performance rests on the hypothesis that, as firms gather to a sufficient level a large amount of broad knowledge that covers a wide spectrum of topics, it will take time for firms to distill relevant knowledge that can lead to innovations. In other words, firms need to first absorb, process, and then internalize the knowledge before knowledge value can be realized (Ferreras-Méndez et al., 2015). As exploratory learning refers to the firm's ability to identify and attain relevant knowledge from the market, its breadth of market knowledge also demonstrates its broad experience in retrieving information about various market aspects or various types of information. Through exploratory learning, it is 
possible that the knowledge attained is partially duplicated or redundant (Prabhu, Chandy, and Ellis, 2005).

On the other hand, firms acquire broad market knowledge by frequently interacting with various stakeholders, groups, or organizations and are thus better equipped to search broadly, and to identify and attain various types of market intelligence. When firms possess broad knowledge, they gain an overall understanding of, and sensitivity to the various sectors or phenomena in the current market (Berkhout, Hartmann, and Trott, 2010). Hence, exploitative learning would make it easier for firms to learn and internalize new knowledge and know how to utilize and organize the knowledge about various aspects of the market. It is easier for firms to know how to improve themselves and learn based on their existing knowledge base. Therefore, exploitative learning can facilitate the increase in firms' competence and in turn increase their innovation performance (Tzokas et al., 2015). Hence, the current study proposes the following hypothesis:

H3-c: Ambidextrous learning (exploitative and exploratory) mediates the positive relationship between market knowledge breadth and innovation performance (process, product).

\section{Methodology}

\subsection{Sample and data collection}

To test the hypotheses, this study utilized a sample of Taiwanese travel agencies listed on the official website of the Tourism Bureau of the Taiwan Ministry of Transportation and Communications in 2016. Given the intensely competitive nature of the tourism industry, travel agencies are compelled to develop new travel products or improve their existing services to enhance their competitive positions in the market (Abou-Shouk, Lim, and Megicks, 2016). The survey recipients in this study consisted of CEOs or senior managers of travel agencies in the capital city of Taipei, Taiwan, which is one of the wellestablished headquarters for business in East Asia.

\subsection{Measures}

All of these measures were drawn from the existing literature, after which they were translated and adapted for the context of the present study. This study focused on six primary constructs: the depth and breadth types of market knowledge (Zhou and Li, 2012), exploitative and explorative learnings (Jansen et al., 2005; Tzokas et al., 2015), and process and product innovations (Chang et al., 2015; Paladino, 2008; Wang and Ahmed, 2004). each of the constructs included three items that were measured on a 7point Likert scale ranging from 1 (strongly disagree) to 7 (strongly agree). Since the measurement scales were established in the West and the surveys were administered in Chinese, back translation was performed to ensure the accuracy of the translation (Brislin, 1980). In addition, potential key informant bias was examined by performing t- 
tests on the constructs' mean differences between the informants in the first wave and those in the second wave (Vorhies, Orr, and Bush, 2011). No significant differences were found at the $p$-value $<0.05$ level, thus providing confidence that non-response bias was not an issue in the present study (Armstrong and Overton, 1977).

\subsection{Measurement of control variables}

To isolate the nature of the relationship among the two types of market knowledge, the two learning capabilities, and the two innovations, it was important to provide controls for other variables that were likely to have an impact on relational performance. To control possible intervening effects, this study employed three control variables: firm size, firm capital, and firm age.

\section{$4 \quad$ Results}

\subsection{Descriptive statistics results}

Among the firms that replied, $79.1 \%$ possessed capital of below NTD $\$ 20$ million, $90.8 \%$ were in one of two categories, i.e., below 50 employees or between 51 and 100 employees, and approximately $90 \%$ of the firms had a turnover of less than NTD\$10 billion. In addition, one-third of the firms have been conducting their business operations for less than 5 years, while the others have been in the business between 6 and 10 years. No significant differences were found using t-tests at the 0.05 level, providing confidence that non-response bias was not an issue in the present study (Armstrong and Overton, 1977).

\subsection{Reliability and validity}

Following the two-stage approach suggested by Anderson and Gerbing (1988), this study used LISREL 8.80 to test the reliability and validity of the estimated measurement model prior to assessing the structural relationships. This study also used Cronbach's $\alpha$ coefficient to measure reliability. The results showed that all of the construct reliability values were greater than 0.70 (Anderson and Gerbing, 1988). In regard to validity, since the contents of the questionnaires were based on relevant literature and reviewed by experts/scholars, the scales included considerable content validity. Moreover, this study used confirmatory factor analysis (CFA) to examine construct validity. All of the observed variables reached a level of significance, and the estimated parameters for the factor loadings conformed to the 0.5 criteria (Anderson and Gerbing, 1988). In addition, the average variance extracted (AVE) was near (or met) the recommendation value of .50 or greater, as proposed by Bagozzi and $\mathrm{Yi}$ (1988), while the composite reliability (CR) met the threshold value of 0.60 or greater. Hence, the measurement model used in this study showed appropriate convergent validity. 
For the discriminant validity test, the AVE root mean square of all of the constructs was required to be greater than the correlation coefficients of the various constructs (Hair, Anderson, Tatham, and Black, 1998). Since the constructs were correlated, but not identical, this criterion also showed reasonable discriminant validity (see Table 1, the means and standard deviations were also shown in this Table). In sum, the reliability, validity, and goodness-of-fit for the measurement model were generally acceptable.

Table 1: Descriptive analysis and correlation ship for all variables

\begin{tabular}{|c|c|c|c|c|c|c|c|c|c|c|}
\hline Construct & Mean S.D & 1 & 2 & 3 & 4 & 5 & 6 & 7 & 8 & 9 \\
\hline Knowledge depth & 6.0130 .861 & $1(.69) 1$ & & & & & & & & \\
\hline Knowledge width & 5.3881 .023 & 30.554 & (.87) 1 & & & & & & & \\
\hline Explorative learning & 5.1901 .191 & 10.469 & 0.674 & (.73) 1 & & & & & & \\
\hline Exploitative learning & 5.1591 .155 & 50.382 & 0.547 & 0.636 & $(.71) 1$ & & & & & \\
\hline Process innovation & 5.4011 .110 & 00.455 & 0.555 & 0.671 & 0.738 & $(.69) 1$ & & & & \\
\hline Product innovation & 5.5471 .077 & 70.443 & 0.508 & 0.630 & 0.657 & 0.732 & (.87) 1 & & & \\
\hline Firm size & 1.2050 .742 & 20.194 & 0.139 & 0.104 & 0.053 & 0.186 & 0.134 & 1 & & \\
\hline Firm scale & 1.4601 .191 & 10.193 & 0.113 & 0.059 & 0.047 & 0.183 & 0.138 & 0.846 & 1 & \\
\hline Firm age & 3.7072 .045 & 50.043 & 0.018 & -0.017 & $7-0.090$ & -0.103 & 0.013 & 0.344 & 0.335 & 1 \\
\hline $\begin{array}{l}\text { Note: } \\
\text { ( ) reports the squar } \\
\text { Firm size: } \\
1=50 \text { employees o } \\
\text { (under) } 1000 \text { emplo } \\
\text { Firm capital: } \\
1=\text { under } 1 \text { years, } 2 \\
10 \text { years } \\
\text { Firm age: } \\
1=\text { under } 5 \text { years, } 2 \\
\text { (under) } 25 \text { years, } 6\end{array}$ & $\begin{array}{l}\text { oot of AV } \\
\text { elow, } 2=5 \\
\text { es, } 5=10 \\
1-\text { (under) }\end{array}$ & $\begin{array}{l}:{ }^{*} p< \\
- \text { (uno } \\
0-(\text { un } \\
3 \text { year }\end{array}$ & $\begin{array}{l}05 \\
\text { er) } 10 \\
\text { er) } 20 \\
3=3\end{array}$ & $\begin{array}{l}\text { emplc } \\
0 \text { em } \\
\text { (unde }\end{array}$ & $\begin{array}{l}\text { ees, } 3 \\
\text { oyees } \\
6 \text { ye }\end{array}$ & $\begin{array}{l}100-(u \\
\text { and } 6=\text { hi } \\
\text { s, } 4=6-\end{array}$ & $\begin{array}{l}\text { under } \\
\text { highe } \\
\text { - (unc }\end{array}$ & $\begin{array}{l}0 \\
10\end{array}$ & $\begin{array}{l}\text { oye€ } \\
\text { s, a }\end{array}$ & $\begin{array}{l}4=500- \\
\text { yees } \\
\bar{b}=\text { over }\end{array}$ \\
\hline
\end{tabular}

\subsection{Common method variance}

All of the measures in this study were based on the responses of the participants. Thus, the reported relationships may be influenced by common method variance (CMV). Considering the validity of the self-reported questionnaires, this study checked for possible CMV by using Harman's single-factor test (Podsakoff, MacKenzie, Lee, and Podsakoff, 2003). Typically, in a single-factor test, all of the items in a study are subject to exploratory factor analysis (EFA). As an alternative to EFA, it is possible to use CFA when implementing Harmon's single-factor test. In particular, CFA can model all of the manifested items, as indicators of a single factor that represents the methodology's effects (Malhotra, Kim, and Patil, 2006). In the single-factor model of the present study, there was one item that failed the criterion for the measurement, indicating this model did not yield a better result than the present model. Thus, there was no significant issue regarding $\mathrm{CMV}$ in this study. 


\subsection{Hypotheses tests}

Basically, under the significance level of $p<0.05$ and the one-tailed t-test value of $>$ 1.65 , some of the hypotheses were confirmed, whereas the others were not supported (see Figure 1).

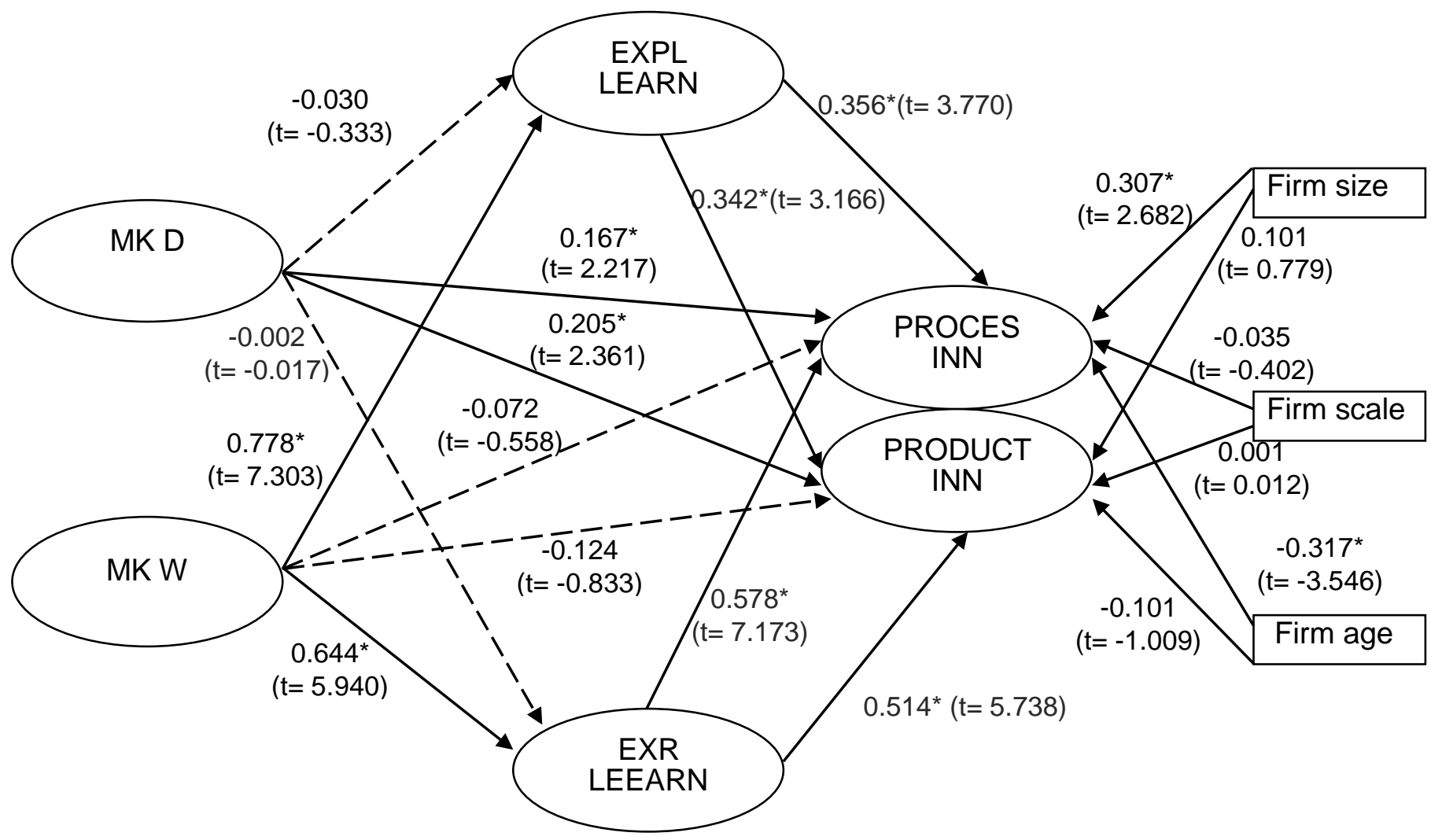

The total effect of MKD on IMM: $0.155 \dagger(t=1.614)$; on IPD: $0.194^{*}(t=1.911)$

The total effect of MKW on IMM: $0.577^{*}(t=5.564)$; on IPD: $0.472^{*}(t=4.410)$

The indirect effect of MKD on IMM: $-0.012^{*}(\mathrm{t}=-0.169)$; on IPD: $-0.011^{*}(\mathrm{t}=-0.177)$

The indirect effect of MKW on IMM: $0.649^{*}(t=5.364)$; on IPD: $0.596^{*}(t=4.664)$

${ }^{*} p<0.05, \dagger p<0.10$

\section{Figure 1: Research Framework}

Based on the test results between market knowledge depth and the two innovations, both $\mathrm{H} 1-\mathrm{a}$ and $\mathrm{H} 1-\mathrm{b}$ were supported $(\mathrm{y}=0.167, \mathrm{t}=2.217 ; \mathrm{y}=0.205, \mathrm{t}=2.361)$, indicating that a travel agency's market knowledge depth has a significant positive effect on product and process innovation. For the test of $\mathrm{H} 2-\mathrm{a}$ and $\mathrm{H} 2-\mathrm{b}$, market knowledge breadth did not have a significant positive influence on product innovation ( $\mathrm{\gamma} 21=-0.072, \mathrm{t}=-0.558)$ and process innovation $(\mathrm{\gamma} 21=-0.124, \mathrm{t}=-0.833)$, indicating that the breadth of market knowledge is not positively associated with the two innovations.

Next, this study examined the relationships between the two learning capabilities and the two innovations. First at all, exploitative and explorative learnings had a significant 
positive influence on product innovation, respectively $(\beta=0.342, t=3.166 ; \beta=0.514, t=$ 5.738). This suggests that product development among travel agencies appears to be influenced by learning capability, especially explorative learning. Meanwhile, exploitative and explorative learnings had a direct positive effect on process innovation $(\beta=0.356, t=$ 3.770; $\beta=0.578, t=7.173$ ). This finding indicates that the importance of ambidextrous learning for business process management should be highly emphasized in process innovation in travel industry. Especially, this positive relationship was also verified in regard to explorative learning. Accordingly, $\mathrm{H} 3-\mathrm{a}$ was confirmed.

In regard to the total effect and indirect analyses, although market knowledge depth had a total direct and slightly positive association with process innovation $(Y=0.155, t=1.614$, $p$-value $<0.10)$ and product innovation $(y=0.194, t=1.911, p$-value $<0.05)$, it did not have a significant indirect influence on the two innovations $(\gamma=-0.012, t=-0.169 ; \mathrm{y}=$ $-0.011, t=-0.177)$. From the one-single-path viewpoint, the two learning capabilities were not significantly influenced by market knowledge depth $(\mathrm{y}=-0.030, \mathrm{t}=-0.333 ; \mathrm{y}=$ $-0.002, t=-0.017)$. By combining the previous empirical results between market knowledge depth and the two innovations, this finding indicates that learning capability does not mediate a positive relationship between market knowledge depth and innovation. Therefore, H3-b was not confirmed (Baron and Kenny, 1986).

For H3-c analysis, market knowledge breadth did not have a positive impact on the two innovations, based on the one-single-path viewpoint. However, market knowledge breadth had an indirect, positive association with the two innovations $(\gamma=0.596, t=4.664$; $Y=0.649, t=5.364)$. The total effect of market knowledge breadth on product innovation $(y=0.472, t=4.410)$ and process innovation $(y=0.577, t=5.564)$ was supported, while the two innovations were directly influenced by learning capability. Moreover, market knowledge breadth had a significant positive influence on both exploitative learning $(\mathrm{y}=$ $0.778, t=7.303)$ and explorative learning $(y=0.644, t=5.940)$.

\section{Table 2: Results of empirical test and rival model comparison}

\begin{tabular}{|l|l|l|}
\hline Hypothesis & results & note \\
\hline $\begin{array}{l}\text { H1-1: the positive effect of market knowledge depth on } \\
\text { product innovation }\end{array}$ & supported & \\
\hline $\begin{array}{l}\text { H1-2: the positive effect of market knowledge depth on } \\
\text { process innovation }\end{array}$ & supported & \\
\hline $\begin{array}{l}\text { H2-1: the positive effect of market knowledge breadth on } \\
\text { process innovation }\end{array}$ & $\begin{array}{l}\text { mix } \\
\text { supported }\end{array}$ & $\begin{array}{l}\text { Direct effect does not } \\
\text { exist, but total effect do } \\
\text { because of learning } \\
\text { capability }\end{array}$ \\
\hline $\begin{array}{l}\text { H2-2: the positive effect of market knowledge breadth on } \\
\text { product innovation }\end{array}$ & $\begin{array}{l}\text { mix } \\
\text { supported } \\
\text { H3-1: the positive effects of exploitative and explorative } \\
\text { on process and product innovation }\end{array}$ & supported \\
\cline { 1 - 2 } H3-2: Ambidextrous learning (exploratory and & $\begin{array}{l}\text { not } \\
\text { supported } \\
\text { exploitative) mediates the positive relationship between } \\
\text { market knowledge depth and innovation performance } \\
\text { (process, product). }\end{array}$ & $\begin{array}{l}\text { Only direct effect } \\
\text { between market } \\
\text { knowledge depth and } \\
\text { two innovation } \\
\text { performances }\end{array}$ \\
\hline
\end{tabular}


H3-3: Ambidextrous learning (exploitative and supported exploratory) mediates the positive relationship between market knowledge breadth and innovation performance (process, product).

\section{Introduction}

\subsection{Discussion}

Past research on the effect of market knowledge on innovation has been especially fruitful. The current study is grounded on the fruits of past research which seeks to, first, answer the call of scholars to more thoroughly investigate the effects of different aspects of market knowledge on innovation performance and, second, delve more deeply into the reasons why past research has yielded such inconsistent results, examining the possibility that it was related to the lack of differentiation of different types of innovation performance (Bao et al., 2012; Chang et al., 2015; Ferreras-Méndez et al., 2015).

In another respect, knowledge exploration and exploitation is one of the important topics of knowledge management today. Hence, it is indeed the management's critical responsibility to establish appropriate knowledge exploration and exploitation mechanisms within the firm to create sustainable competitive advantages for the firm and in turn increase performance. In the past, scholars argued based on the KBT of the firm which holds that the mediating mechanism impacting the effect of market knowledge on innovation is rooted in the firm's knowledge integration mechanism which stresses systematic knowledge management (e.g., De Luca and Atuahene-Gima 2007; Tsou and Chen, 2012). In general, unless firms have ample capital resources, not all of them can effectively introduce knowledge management investments. Therefore, the current study proposes that the organizational learning capabilities of a firm is the key to converting market knowledge to innovation performance, by drawing from the KBT, inheriting the logic in the input-process-output framework, and adopting the perspective of ambidextrous learning in the discipline of organizational behavior.

The study findings illustrate the following. First, while market knowledge depth has a significant effect on both types of innovation performance, market knowledge breadth does not. This finding also addresses the issue of inconsistent findings on the effects of market knowledge on innovation in past research, which was due to the fact that market knowledge and innovation performance were viewed as singular constructs, thus masking the true effects. Second, the inconsistency in the study findings about the effect of market knowledge on innovation performance could also be attributed to not examining innovation performance more thoroughly. The empirical results show that market knowledge depth impacts product innovation slightly more than process innovation, although the difference in effect did not reach a significant level. At least, such finding establishes for future research the evidence that different market knowledge types do 
affect different types of innovation performances differently and that the level of significance could vary. Finally, different learning capabilities do play a mediating role in the impact of market knowledge on innovation performance. More interestingly, in terms of the effect of market knowledge breadth on innovation performance, exploitative learning has a more pronounced mediating effect than exploratory learning. This finding not only explains why market knowledge has not been found to positively impact innovation performance and why any such impact, when found, has been inconsistent, but also reveals that a particular type of learning capability could better mediate the effect of certain market knowledge type on innovation performance. The current study not only applies existing theories but also provides a research foundation based on empirical evidence for subsequent research.

\subsection{Theoretical contribution}

Today, in the 21 century, the majority of firms are already market-oriented. In order to deliver different performance, firms will rely on their knowledge about the market of their respective industries. Based on the analysis results of the current study, the management implications are as follows. First, the current study not only examines the necessity of the relationship between market knowledge types and different types of innovation performance (product, process), but also addresses the reasons why recent research has found an insignificant or negative relationship between market knowledge and innovation performance. In recent years, although scholars have applied the KBT to examine the impact of different market knowledge types on firms' innovation performance, the inconsistent findings could also be attributed to not examining innovation performance more thoroughly in past research. Hence, the current study continues the past research thread that investigates the causal relationships between different types of market knowledge and different types of innovation performances.

Second, the current study extends the explanatory power of the KBT by elucidating the different effects of various knowledge dimensions on various types of innovation. The current study compares the various effects of various market knowledge dimensions on innovation performance. Although past research has examined the effect of different types of market knowledge on product innovation, few studies have examined the differing effects of differing types of market knowledge as well as the differing effects of a particular market knowledge dimension on different types of innovation performance-the current study provides this very perspective and elucidation. The empirical results show that market knowledge depth impacts product innovation slightly more than process innovation. Although this effect is not statistically significant, these findings could inspire researchers studying this type of topics to consider a practical question, namely, how a firm's market knowledge could have different effects on its innovation performance.

Overall, the current study demonstrates that despite the continued spread of firm's market knowledge, if the employees cannot master such knowledge through a 
comprehensive study, learn, and put the knowledge to use, the ultimate performance still cannot be realized (Roth, Jayachandran, Dakhli, and Colton, 2009; Tzokas, Kim, Akbar, Al-Dajani, 2015). This may also explain why some studies find no impact of market knowledge on innovation performance (Ferreras-Méndez et al., 2015; Jansen et al., 2005).

\subsection{Management Practices}

As the empirical results demonstrate that market knowledge depth can have an important impact, in terms of management practices, firms should spare no efforts to acquire the market knowledge of their respective market sectors. Although market knowledge breadth does not directly impact innovation performance, we recommend that firms broaden their markets based on the scale of their operations or their surplus of resources in order to accumulate market knowledge and expand their knowledge breadth. How should firms increase the effectiveness of market knowledge breadth on innovation performance? In terms of strategic management, we recommend that reward mechanisms for market knowledge acquisition should be set up, as well as policies providing subsidies for employees' on-the-job training should be implemented. A firm is a composite of knowledge. Such knowledge is the sum of employee knowledge and skill sets pooled together through an operational mechanism (Day, 1994; Grant, 1996). Therefore, in terms of human resources management, firms should encourage employees to understand the market need through frequent interactions with customers or focus groups as well as frequent contact with and learning from major upstream and downstream suppliers. Besides, when new technologies or new industry knowledge become available on the market, firms should host occasional seminars from and invite experts with related specialties to be speakers, thus facilitating an accumulation firm's market knowledge depth and breadth.

\subsection{Limitation and recommendation}

Despite its obvious contributions and procedural preventions (CMV and robustness check), this study includes some inherent limitations. First, due to the cross-sectional nature of the data, additional research should adopt a longitudinal approach and the data should be collected at different times. Second, the empirical results of this study were only obtained in Asia. Thus, future research should test for nationality bias (e.g., in the United States or Europe) to overcome any context-specific issues. Finally, this study utilized the depth and breadth of knowledge to represent the antecedents of innovation performance. Although it was valid and meaningful, future research should develop multidimensional measures (De Luca \& Atuahene-Gima, 2007) that consider more specific knowledge characteristics, and empirically test their effects on various innovation indices. 


\section{Reference}

Chang, J., Bai, X., and Li, J. J., (2015). The influence of leadership on product and process innovations in China: The contingent role of knowledge acquisition capability. Industrial Marketing Management, 50, 18-29.

Kumar, V., Jones, E., Venkatesan, R., and Leone, R. P. (2011). Is market orientation a source of sustainable competitive advantage or simply the cost of competing?. Journal of Marketing, 75(1), 1630 .

De Luca, L. M., and Atuahene-Gima, K. (2007). Market knowledge dimensions and cross-functional collaboration: Examining the different routes to product innovation performance. Journal of Marketing, 71(1), 95-112.

Cohen, W. M., and Levinthal, D. A. (1990). Absorptive capacity: A new perspective on learning and innovation. Administrative Science Quarterly, 35(1), 128-152.

Bao, Y., Sheng, S., and Zhou, K. Z. (2012). Network-based market knowledge and product innovativeness. Marketing Letters, 23(1), 309-324.

Bagozzi, R. P., and Yi, Y. (1988). On the evaluation of structural equation models. Journal of The Academy of Marketing Science, 16(1), 74-94.

Ferreras-Méndez, J. L., Newell, S., Fernández-Mesa, A., and Alegre, J. (2015). Depth and breadth of external knowledge search and performance: The mediating role of absorptive capacity. Industrial Marketing Management, 47, 86-97.

Im, S., and Workman Jr, J. P. (2004). Market orientation, creativity, and new product performance in hightechnology firms. Journal of Marketing, 68(2), 114-132.

Kim, N., and Atuahene-Gima, K. (2010). Using exploratory and exploitative market learning for new product development. Journal of Product Innovation Management, 27(4), 519-536.

Li, T., and Calantone, R. J. (1998). The impact of market knowledge competence on new product advantage: Conceptualization and empirical examination. Journal of Marketing, 62(4), 13-29.

Moorman, C. (1995). Organizational market information processes: Cultural antecedents and new product outcomes. Journal of Marketing Research, 32(4), 318-335.

Tsou, H. T., and Chen, J. S. (2012). The influence of interfirm codevelopment competency on e-service innovation. Information and Management, 49(3), 177-189. 
Glazer, R. (1991). Marketing in an information-intensive environment: Strategic implications of knowledge as an asset. The Journal of Marketing, 1-19.

Chen, K. Y. and Lee, C. F. (2017). Market knowledge of the travel industry from knowledge-based view: A case of two Taiwanese travel agencies, Asia Pacific Journal of Tourism Research, 22(7), 781-797.

Kostopoulos, K., Papalexandris, A., Papachroni, M., and loannou, G. (2011). Absorptive capacity, innovation, and financial performance. Journal of Business Research, 64(12), 1335-1343.

O'Reilly, C. A., and Tushman, M. L. (2008). Ambidexterity as a dynamic capability: Resolving the innovator's dilemma. Research in Organizational Behavior, 28, 185-206.

Zhou, K. Z., and Li, C. B. (2012). How knowledge affects radical innovation: Knowledge base, market knowledge acquisition, and internal knowledge sharing. Strategic Management Journal, 33(9), 10901102.

March, J. G. (1991). Exploration and exploitation in organizational learning. Organization Science, 2(1), 7187.

Clark, D. (2010). Chip firms detail alliance to combat Intel. The Wall Street Journal, (accessed Aug 24, 2016), available at http://online.wsj.com/article/SB10001424052748703525704575061560284134240.html.

Christensen, C.M. (2006). The ongoing process of building a theory of disruption. Strategic Management Journal, 23(1), 39-55.

Chen. H., Li, Y., and Liu, Y. (2015). Dual capabilities and organizational learning in new product market performance. Industrial Marketing Management, 46, 204-213.

Gopalakrishnan, S., and Damanpour, F. (1997). A review of innovation research in economics, sociology and technology management. Omega, 25(1), 15-28.

Dougherty, D., Borrelli, L., Munir, K., and O'Sullivan, A. (2000). Systems of organizational sensemaking for sustained product innovation. Journal of Engineering and Technology Management, 17(3), 321-355.

Johnson, M. W., Christensen, C. M., and Kagermann, H. (2008). Reinventing your business model. Harvard Business Review, 86(12), 57-68.

Schindehutte, M., Morris, M. H., and Kocak, A. (2008). Understanding market-driving behavior: The role of entrepreneurship. Journal of Small Business Management, 46(1), 4-26

Jansen, J. J. P., Van den Bosch, F. A. J., and Volberda, H. W. (2005). Managing potential and realized 
absorptive capacity: How do organizational antecedents matter?. Academy of Management Journal, 48(6), 999-1015.

Morgan, N. A., Zou, S., Vorhies, D. W., and Katsikeas, C. S. (2003). Experiential and informational knowledge, architectural marketing capabilities, and the adaptive performance of export ventures: A cross-national study. Decision Sciences, 34(2), 287-321.

Nieves, J., and Haller, S. (2014). Building dynamic capabilities through knowledge resources. Tourism Management, 40, 224-232.

Tzokas, N., Kim, Y. A., Akbar, H., and Al-Dajani, H. (2015). Absorptive capacity and performance: The role of customer relationship and technological capabilities in high-tech SMEs. Industrial Marketing Management, 47, 134-142.

Kale, P., Dyer, J. H., and Singh, H. (2002). Alliance capability, stock market response, and long-term alliance success: The role of the alliance function. Strategic Management Journal, 23(8), 747-767.

Prabhu, J. C., Chandy, R. K., and Ellis, M. E. (2005). The impact of acquisitions on innovation: Poison pill, placebo, or tonic?. Journal of Marketing, 69(1), 114-130.

Berkhout, G., Hartmann, D., and Trott, P. (2010). Connecting technological capabilities with market needs using a cyclic innovation model. $R \& D$ Management, 40(5), 474-490.

Wang, C. L., and Ahmed, P. K. (2004). The development and validation of the organisational innovativeness construct using confirmatory factor analysis. European Journal of Innovation Management, 7(4), 303-313.

Paladino, A. (2008). Analyzing the effects of market and resource orientations on innovative outcomes in times of turbulence. Journal of Product Innovation Management, 25(6), 577-592.

Armstrong, J. S., and Overton, T. S. (1977). Estimating nonresponse bias in mail surveys. Journal of Marketing Research, 396-402.

Anderson, J. C., and Gerbing, D. W. (1988). Structural equation modeling in practice: A review and recommended two-step approach. Psychological Bulletin, 103(3), 411.

Bollen, K. A., and Long, J. S. (1992). Tests for structural equation models. Sociological Methods and Research, 21(2), 123-131.

Vorhies, D. W., Orr, L. M., and Bush, V. D. (2011). Improving customer-focused marketing capabilities and firm financial performance via marketing exploration and exploitation. Journal of the Academy of Marketing Science, 39(5), 735-756. 
Hair, J. F., Black, W. C., Babin, B. J., Anderson, R. E., and Tatham, R. L. (1998). Multivariate data analysis. Upper Saddle River, NJ: Prentice hall.

Podsakoff, P. M., MacKenzie, S. B., Lee, J. Y., and Podsakoff, N. P. (2003). Common method biases in behavioral research: A critical review of the literature and recommended remedies. Journal of Applied Psychology, 88(5), 879.

Malhotra, N. K., Kim, S. S., and Patil, A. (2006). Common method variance in IS research: A comparison of alternative approaches and a reanalysis of past research. Management Science, 52(12), 1865-1883.

Roth, M. S., Jayachandran, S., Dakhli, M., and Colton, D. A. (2009). Subsidiary use of foreign marketing knowledge. Journal of International Marketing, 17(1), 1-29.

Baron, R. M., and Kenny, D. A. (1986). The moderator-mediator variable distinction in social psychological research: Conceptual, strategic, and statistical considerations. Journal of Personality and Social Psychology, 51(6), 1173-1182.

Day, G. S. (1994). The capabilities of market-driven organizations. The Journal of Marketing, 37-52.

Grant, R. M. (1996), Toward a knowledge-based theory of the firm. Strategic Management Journal, 17(s), 109-122. 